\title{
Taxonomic Values of Pollen Features in Sanna Genus (Fabaceae) from South- Eastern Nigeria
}

\author{
${ }^{1}$ Nnamani, C. V, and ${ }^{2}$ Onu. E. \\ ${ }^{1}$ Plant Taxonomy/Biosystematics and Palynology/Palaeoecological Unit, \\ Department of Applied Biology, Ebonyi State University, Abakaliki, Nigeria. \\ ${ }^{2}$ Department of Applied Biology, Ebonyi State University, Abakaliki, Nigeria.
}

\begin{abstract}
Pollen features of five Senna species belonging to the Fabaceae were accessed palynologically after standard acetolysis methods. Their qualitative and quantitative features were determined by light microscopy (L. M.) in order to identify the observable peculiarities with respect to their taxonomic significance. These species are Senna obtusifolia (Linn.) H. S. Irwin and Barney, Senna occidentalis (Linn.) Link, Senna hirsute (Linn.) H. S. Irwin and Barney, Senna alata (Linn.) Roxb and Senna podocarpa (Guill.). Results revealed many interesting palynological features which are congruent with the taxonomy of this genus. Pollen were eurypalynous in nature, radially symmetrical, shed in monads and isopolar in all the taxa. They are all eudicot, with tricolporate apertural type, with coarse scabrate to scabrate in ornamentation. Shapes of pollen grains were subprolate for S. hirsuta and S. obtusifolia, spheriodial for S. podocapa and S. occidentalis, it was prolate for S. alata. Pollen shapes in polar view is circular for S. hirsuta and S.alata. S. occidentalis had the highest pollen size in equatorial view length $(E V L)(16.5 \pm 1.11)$, while in polar view length $(P V L) S$. hirsuta had the highest size of $(15.25 \pm 0.73)$. There was no significant difference $(p<0.5 \%)$ in the exine thickness and polar diameter for these species. The taxonomic implications of these similarities were discussed.
\end{abstract}

Keywords: Palynology, Pollen Features, Taxonomic values, Senna species, South-eastern Nigeria

\section{Introduction}

Charya et al. (2011) reported that Senna Mill. is a large and diverse genus, that was formerly part of Cassia L. together with Chamaecrista Moench. It belongs to the Fabaceae formally (Leguminosae, Caesalpinioideae, Cassiinae). Senna is one of the twenty-five largest genera of dicotyledonous plants in the world, with many members of the genus extending to all terrestrial habitats, from the equator to the edges of dry and cold deserts, but much of its diversity is centered within the tropics. Marazzi et al., (2006) noted that the separation of Cassia s. l. into Cassia s.str., Chamaecrista and Senna Irwin and Barneby (1981), Irwin and Barneby (1982), was supported by morphological studies Endress, (1994), Tucker (1996b) and molecular phylogenetic studies Bruneau et al, (2001), Herendeen et al., (2003) and Marazzi et al., (2006) . The above separation was equally confirmed by the taxonomic reclassification arising from the work of Randell, (1989), Randell, (1990), Randell, and Barlow (1998) and Singh, (2001)], structural analysis by Endress, (1994), Tucker (1996b) and phenetic studies.

About 260 species in this genus are distributed within the tropics and temperate regions. However, Burkil, and Lewis, (2003) noted that 19 species are found in West African with these 19 species found in Nigeria. The genus consists of herbs, shrubs, tree lets, tall trees and lianas. They have successfully colonized a wide range of habitats in different climates and latitudes with a large number of them been ornamental and roadside plants (Burkill, 1995).

Currently, this genus has followed several probing lines of classification, because of the extreme morphological resemblances and ambiguous boundaries between taxa (Soladoye et al., 2010).

This unstable taxonomic boundary is mainly due to difficulty in the taxonomic identification and interpretation of common similar morphological features in the Senna genus. Marazzi et al. (2006) noted that the high degree of specialization typical of the buzz-pollinated Senna flowers complicates the identification of characters which can be unambiguously used for their taxonomic identification and delineation.

Medicinally, roots of some Senna species are considered as diuretic and a decoction is used topically to treat fever, while fresh or dried leaves are crushed and applied externally for skin disorders, wounds, parasitic skin diseases and abscess (Bin-hafeez, 2001). Tona and Elujoba (2004) stated that Senna spp have potential as antihypertensive drugs. It has demonstrated significantly in antihepatotoxic (liver protective), hepatotonic (liver tonic), and hepatic detoxification (liver detoxifying) effects in animals (Adeyemi and Abo 2002). Leaves of Senna podocarpa can be mixed with shea butter to smoothing the body while the roots of S. occidentalis according to Clark and Dively (2001) and Evans (2000) are considered as tonic to reduce fever.

Economically Senna species can be used as ornamentals, weeds and food for man. Young pods of $S$.. occidentalis are steamed or cooked in vegetable dishes or in salads while seeds are brewed into a coffee- like 
beverage for asthmatic patients (Mike et al., 2005). It can also be roasted and boiled in water to produce tea. Commercial gum is extracted from species of Cassia. Andrew and Brower (2006) noted that wide varieties of these species are ecologically adapted for climate change mitigation.

Pollen characters are good taxonomic tool because many pollen traits are not influenced by the strong selective forces. Acharya et al., (2011) noted that despite numerous studies by taxonomists, either on the whole subfamily Caesalpinioideae in restricted areas or of certain genera throughout the world, there is still a great deal of taxonomic work to be done at the level of genus and tribe. This is because taxonomy today is not simply based on floral and vegetative characters, but rather seeks to generate data from anatomical, cytological, serological, palynology and molecular to authenticate morphological traits. Data from such branches are currently very important in determining relationships and affinities of plants.

They have been utilized by many researchers to aid the identification and reclassification of many families of angiosperms with conflicting taxonomic peculiarities and have enabled taxonomists as well as ecologist to classify and reconstruct environmental changes of plant over time (Moore and Webb, 1975, Nnamani and Nwosu, 2012). Bearing the above facts in mind coupled with their high medicinal, food, and socio-economic values implicated in some members of this genus, pollen morphology of Senna becomes imperative. The major aim of this work was to generate a quantitative and qualitative data from their palynological features in order to generate data concerning these Nigerian species. The specific objectives were to proffer answers to these questions, 1) which of these morphological traits are congruent within these species and 2) what are their taxonomic implications.

\subsection{Sample Collection And Preparation}

\section{Materials And Methods}

Fresh polleniferous buds from S. obtusifolia, S. occidentalis, S. hirsuta, S. alata and S. podocarpa were obtained from cultivated and uncultivated fields within some local communities in South-eastern Nigeria. Samples were identified with the aid of Keay et al., (1964); Keay, (1989) and Inyang, (2003) . Mature buds which had not undergone anthesis were removed from their shoots. Anthers were teased off from the flower buds into five $\mathrm{ml}$ of $70 \%$ alcohol in $25 \mathrm{ml}$ beakers and squashed with a glass rod. This process breaks the anthers to release the pollen grains. The solutions were sieved with fine network mesh of wire gauze (sterilized under the Bunsen Burner to avoid contaminations). This process removed all the plant tissues. The solutions were then centrifuged at 2000 revaluation per a minute (R P M) for 5 minutes, washed twice with distilled water, centrifuged and then decanted again.

\section{2.2. Acetolysis}

The recovered precipitates were acetolyzed according to a modified version of Erdtman, (1971) acetolysis method of 9:1 conc. sulphuric acid and acetic anhydride for ten minutes. They were centrifuged, decanted and wished twice with distilled water. The recovered precipitates were stored in vials with ten drops of glycerin, for subsequent light microscopy.

\subsection{Microscopy}

Temporary slides were prepared from the reserved stock, pollen grains were mounted in glycerin jelly and examined using light Olympus CH Trinocular microscope (LM) fitted with 650 IS Cannon Digital Camera at x 400 and x 100 magnifications. (All measurements and photomicrographs were taken under x 1000 magnification

The following parameters were assessed qualitatively and quantitatively: polar view diameter (DVD), equatorial view diameter (EVD), pollen form index (PFI), exine thickness (IXT), shape in polar view, shape in equatorial view, sculpturing type, aperture type, dimension of pore at polar and equatorial views. Terminology for pollen descriptions were adopted from (Punt. et al., 1994).

\subsection{Statistical Analysis}

Qualitative features were recorded based the observation using light Olympus $\mathrm{CH}$ Trinocular microscope (LM) fitted with 650 IS Cannon Digital Camera at x 400 and x 100 magnifications, while quantitative data were based on 4 measurements for a feature per slide for four slides per a sample. These values were tabulated with the species description citing mean standard errors for some of the important pollen features. Analysis of Variance (ANOVA) was performed to test the differences between some of these features recorded from each taxon. 


\section{Result}

Results from this work gave some interesting data. Pollen grains of these Senna species investigated were all eurypalynous in nature. In polarity and symmetry of pollen, they were all.radially symmetrical, isopolar, generally shed in monads and rarely in tetrads.

\subsection{Pollen Shape}

Pollen shapes were subprolate in S. alata and S. hirsute while it was spheroidal in others; amb in polar view was circular in S. hirsute and S. alata, concave with triangular outline in S. podocarpa, S. obtusifolia and S. occidentalis. Pollen ornamentation was coarse scabrate, tectate for $S$. hirsute and S. alata, without carvae but scabrate in S. podocarpa, S. obtusifolia and S. occidentalis (Table 1).

\subsection{Aperture}

Pollen grains are all tricolporate, zonocolporate and non lophate while pore orientation was angulaperturate (Table 1) with apertural length and breadth of $12.25 \pm 1.36,11.2 \pm 1.3,12.25 \pm 1.29,13.5$ \pm 1.11 and $2.25 \pm 0.25,2.25 \pm 25,1.8 \pm 1.16,1.87 \pm 0.86,2.12 \pm 0.21$ and $6.62 \pm 0.13$, respectively for $S$. hirsute, $S$. podocarpa, S. obtusifolia, S. occidentalis and S. alata (Fig 1).

Table 1: Qualitative Features of 5 Senna species from South-eastern Nigeria

\begin{tabular}{llllll}
\hline Species & APT & NAP & SCPT & SPPV & SPEV \\
\hline S. hirsute & Trico & 3 & Coarse scabrate & Circular & Subprolate \\
S. podocarpa & Trico & 3 & Scabrate & Triangular & Prolate \\
S. obtusifolia & Trico & 3 & Scabrate & Triangular & Prolate \\
S. occidentalis & Trico & 3 & Scabrate & Triangular & Spheriodal \\
S. alata & Trico & 3 & Coarse scabrate & Circular & Prolate \\
\hline
\end{tabular}

Legend: APT $=$ Apertural type, Trico $=$ Tricolporate, NAP $=$ Number of aperture, SCPT $=$ Sculpturing type $\mathrm{SPPV}=$ Shape at polar view, $\mathrm{SPEV}=$ shape at equatorial view

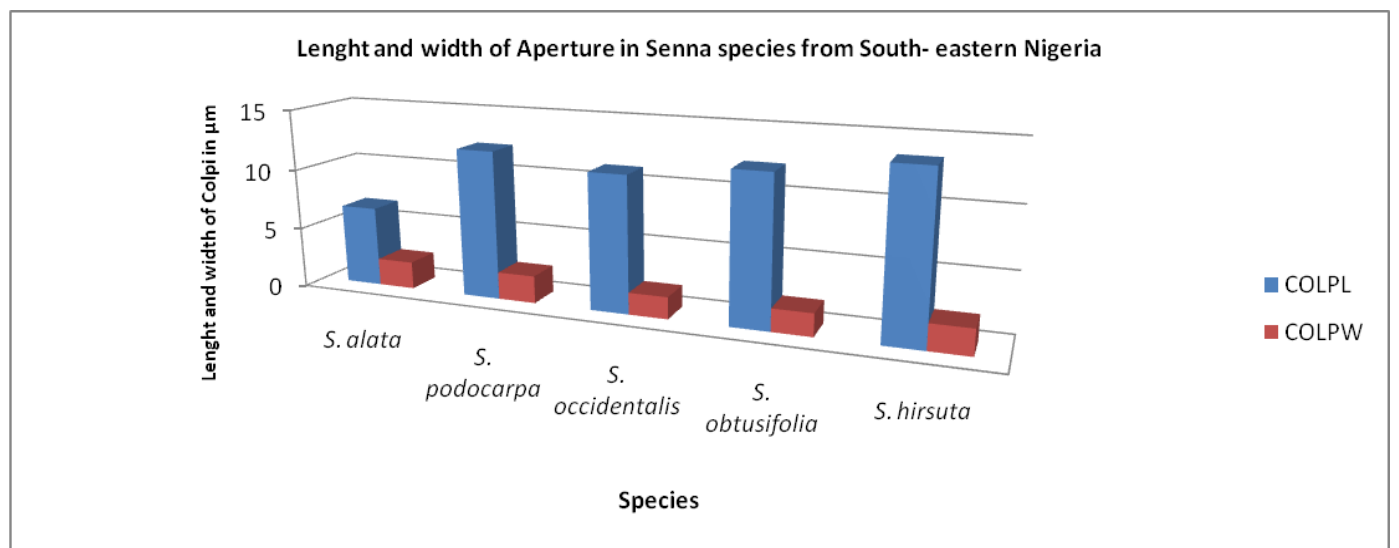

Fig. 1: Length and width of colpi of the 5 Senna species from South-eastern Nigeria

Table 2 below shows the length of pollen in both equatorial and polar views with $S$. occidentalis having the highest equatorial dimension of $16.5 \pm 1.11 \mu \mathrm{m}$ while $S$. hirsute had the highest $15.25 \pm 0.73 \mu \mathrm{m}$ and $11.26 \pm$ $0.82 \mu \mathrm{m}$ for polar view length and polar view diameter, respectively (Table 2 ).

Table 2: Quantitative Data of Pollen Features of the five species of Senna (mean \pm standard error in $\mu \mathrm{m}, \mathrm{x} 100$ ).

\begin{tabular}{llll}
\hline Species & EVL & PVL & PVD \\
\hline S. alata & $9.25 \pm 0.82$ & $8.0 \pm 0.70$ & $4.75 \pm 0.25$ \\
S. podocarpa & $14.5 \pm 1.11$ & $13.5 \pm 1.11$ & $11.25 \pm 1.2$ \\
S. occidentalis & $16.5 \pm 1.11$ & $14.7 \pm 1.34$ & $10.2 \pm 1.47$ \\
S. obtusifolia & 13.250 .82 & $14.0 \pm 0.86$ & $9.5 \pm 0.97$ \\
S. hirsuta & $13.0 \pm 0.70$ & 15.250 .73 & $11.3 \pm 0.8$ \\
\hline
\end{tabular}

Legend: $\mathrm{EVL}=$ Equatorial view length, $\mathrm{PVL}=$ Polar view length, $\mathrm{PVD}=$ Polar diameter,

\subsection{Exine thickness}

The thickness of exine in all the species were relatively thin except for $S$. podocarpa that was $2.5 \mu \mathrm{m}$ while $S$. occidentalis and $S$. hirsuta have the highest width in mesoporium and apoporium respectively (Fig.2). S. alata recorded the lowest values for all the three attributes ie ine thickness, mesoporium and apoporium. 


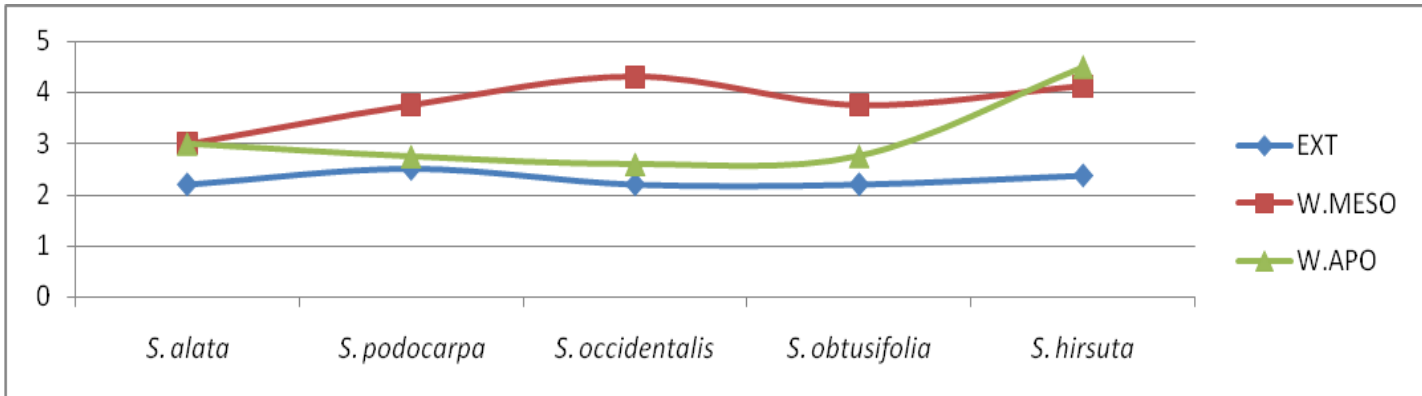

Fig. 2: Exine Thickness, width of mesoporium and apoporiun of the 5 Senna species from South-eastern Nigeria

\section{Discussion}

The data from this pollen - morphological studies on Senna species from South-eastern, Nigeria have furnished important taxonomic data which showed recognizable similarity in some basic features such as apertural numbers and type, pollen symmetry, shape and polarity of pollen corresponding with their tribal classification. Based on these results from this work, it is evident that the existing classification of Senna sensu stricto in Senna is justified since most of these characters are akin, thus facilitating their grouping together in the same genus. These taxonomic evidences in most of the pollen feature could be exploited for systematic purposes. This is in line with the report by] Acharya et al. (2011) noted that data generated from other areas are at present very important in determining relationships and affinities of the plants. The above report is equally supported by Soladoye et al. (2010), who used morphometric features in justifying the delineation of this Senna genus from South-eastern Nigeria.

\subsection{Apertural and Sculpturing Type}

This study recorded tricolporate apertural type in all the species. However, the pollen sculptures for all these Senna species were outstandingly coarse scabrate to scabrate in ornamentation. This could be a reflection of the fact that they are all entomophyllous in nature and this to some extent facilitated their easy adhesion on the bodies of agent dispersal. This is in conformity with the report of Furness and Richard (2004) and Perveen and Oaiser (2007), who reported in their various works that pollen grains do not differ within most families and as such can be of great value in establishing affinity or otherwise. It is also in line with the reports by Mbagwu and Edeoga (2006) and Nnamani and Nwosu (2012), who in their various works utilized apertural attributes of pollen grains to establish probable evidences of relationships among some species of flowering plants and in some members of Clusiaceae family from Nigeria, respectively. They suggested that pollen morphology can be useful in supporting morphological characters and could be used in solving taxonomic controversies in the classification of problematic taxa.

\subsection{Shape of Pollen}

Pollen shapes in polar view were triangular for S. podocarpa, S. obtusifolia and S. occidentalis, circular for $S$. hirusta, and S. alata while the equatorial shapes were subprolate for S. hirsuta, and S obtusifolia, prolate for S. alata, and spheriodal for S. podocarps and S. occidentalis. Lowe and Soladoye (1990) and Ogwal (1990) suggested that, it is likely that the nature or shape of pollen grains could be an evolutionary modification often inherited to determine the mode of pollination and thereby perpetuate a particular group of plant in a given environment. In the same line with the report by Mbagwu and Edeoga (2006) who were of the opinion that, where the pollen grain is longer than wide, it may be explained as a structural adaptation for effective dispersal by wind while the circular nature of some of the pollen grains were related to structural adaptation. In view of the above explanations $S$. podocarps and $S$. occidentalis prolate in shape are highly prolific and gregarious in any habitat where they are found.

\subsection{Pollen Diameter and Exine Thickness}

The diameter of all the pollen grains ranged from $11.25 \pm 0.82$ to $11.25 \pm 1.29$ for all the species (Fig.2). There was no significant difference at $(\mathrm{p}<0.5 \%)$ in the exine thickness and pollen diameter for these species. All these recognizable similarities in these features are in line with the report by Shaheen et al., (2013) who affirmed that similarities in data from morphometric study in Senna species from South-eastern Nigeria corresponded with their tribal classification, reflecting their intergeneric affiliation. These noteworthy similarities in their pollen diameter and shape have provided reasonable taxonomic information to aid in the identification. 


\section{Conclusion}

Although the pollen characters are insufficient to reconstruct the phylogeny of the genus, pollen morphology is useful for the taxonomy at species level. The study of pollen morphology of five species of Senna, S. alata, S. hirusta, S. obtusifolia, S. occidentalis, S. podocarpa, using these quantitative and qualitative characters provided justification for the existing classification of the Senna genus. It has shown that there are some similarities in the micro-morphological features. These included apertural types and numbers, sculpturing nature, shape of pollen in polar view diameter and equatorial view diameter. These gave some taxonomic data for their recognition, identification and subsequent delineation in one genus. Pollen showed recognizable similarity which corresponded with the tribal classification reflecting their intergeneric relationship Applying these similarities in pollen morphology to the species investigated showed that their pollen characters could be used in establishing affinity.

\section{Recommendation}

Owing to the variety of uses and medicinal importance recorded in some members of Senna species such as treating of vegetable, black tea, treatment of infection, skin infection, dysentery, their laxative effects, and because they present future prospects in the production of raw materials for the production drugs, allembracing research needs to be done on the species from South-eastern Nigeria to determine the level of toxicity of their anti- nutritive components. Many more researches should be carried out on the pollen morphologies of other members of the genus Senna to enhance their classification.

\section{References}

[1]. Adeyemi, A. A. and Abo, K. A. (2002). Seasonal Accumulation of Anthroquinones in leaves of cultivated Cassia podocarpa. African Journal of Mecine and Medical Science. 31 (2): 171-173.

[2]. Andrew, V.Z and. Brower, A (2006). Problems with DNA barcodes for species delineation. Systematics and Biodiversity 4(2): $127-132$

[3]. Acharya, L., Mukherjee, A K, and Pratap Chandra Panda, P. C. (2011). Separation of the Genera in the subtribe Cassiinae (Leguminosae: Caesalpinioidae) using Molecular Markers. Acta Botanica Brasilica 25(1): 223-233.

[4]. Bruneau A Forest F Herendeen P. S Klitgaard B. B Lewis G. P 2001. Phylogenetic relationships in the Caesalpinioideae (Leguminosae) as inferred from chloroplast trnL intron sequences. Systematic Botany 26: 487-514.

[5]. Burkil, H.M and Lewis Gap, (2003). A check list of Nigeria Legumes centrad 12-14Pp

[6]. Burkill, H.M, (1995). The useful plants of West Tropical Africa. Second edition, vol 3 Royal Botanical Gardens, Kew. London. 167Pp.

[7]. Bin-hafeez (2001). "Protective Effects of Cassia occidentalis on Cyclophosphainide-induced Suppression of Humoral Immunity in Nice Ethnopharmacology 75(1): 13-18

[8]. Clark, P, and Dively, G.P, (2001). A Cornparative Pollen deposition of milk weeds in near corn fields. Proceedings of the material Academy of science of the United State of America 98(21): 11919 - 11924.

[9]. Evans, C.E (2002). "Efficacy of some Nupe Medicinal plants against salmonella typhi as in vitro study. Ethnopharmacol 80 (1): 2124.

[10]. Endress P. K 1994. Diversity and evolutionary biology of tropical flowers Cambridge University Press ambridge, UK.

[11]. Erdtman, G. (1971). Pollen Morphology and Plant Taxonomy (Angiosperm). Hafner Publishing Company, New York.

[12]. Furness, I.P and Richard, G., (2004). “A Survey of Sennaalata”, American Journal of Botany 91:1627 -1644.

[13]. Herendeen P. S Bruneau A Lewis G. P 2003. Phylogenetic relationships in caesalpinioid legumes: a preliminary analysis based on morphological and molecular data. In B. B. Klitgaard, and A. Bruneau [eds.] Advances in legume systematics, part $1037-62$ Royal Botanic Gardens, Kew, UK.

[14]. Inyang, E. (2003). Ethnobotany, Conventional and Traditional Uses of Plants. Verdict Press, Nigeria.,191, pp.

[15]. Irwin H. S Barneby R. C 1981.Tribe 2. Cassiae Bronn (1822). In R. M. Pohlhill, and P. H. Raven [eds.] Advances in legume systematics, part 197-106 Royal Botanic Gardens Kew, UK.

[16]. Keay, R. W. J., Onochie, C. F. A. and Stanfield, D. P. (1964). Nigerian Trees. Federal Department of Forest Research. Oxford Science Publications, New York. 465, pp.

[17]. Keay, R. W. J. (1989). Trees of Nigeria. Clarendon Press Oxford University Press, New York. 476 pp 27.

[18]. Lowe, H.O and Soladoye (1990).A numerical approach to the phonetic classification of the genus senna Niger. J. Sci 16:59-81.

[19]. Marazzi, B., Endress, P.K., Paganucci de queiroz, L. (2006). Phylogenetic Relationships within Senna (Leguminosae, Cassiinae) based on three Chloroplast Dna Regions: Patterns in the Evolution of Floral Symmetry and Extra floral Nectarine. American Journal of Botany 93(2): 288-303.

[20]. Mike, L., Gwilym, L., Brain, S., and Barbara, M, (2005).Legumes of the words. Royal Botanic Gardens, Kew: Richmon England ISBN 978-1-900347-80-8.

[21]. Moore, P. D. and Webb, J. A. (1975). An Illustrated Guide to Pollen Analysis. Blackwell. Scientific Publications, London, 216, pp.

[22]. Mbagwu C.J and Edeoga, V.A., (2006).Sex ratio in seeds of Rumexacetosa L. as a result of sparse or abundant pollination. "acta boil. Cracov" Scr. Bot., 18, 101-14.

[23]. Nnamani, C. V. and Nwosu, M. O (2012). Pollen Morphology of Some Members of the Nigerian Clusiaceae and Its Taxonomic Significance. Journal of Pharmacy and Biological Sciences 3 (3), 14-19.

[24]. Ogwal, A.U (1990). Facts and Practice for biology. Oxford University press 95Pp.

[25]. Punt. W. W.W., Nilsson, S., Blackmore, S. and Thomas, L. A. (1994). Glossary of Pollen and Spore Terminology, -L P P Foundation, Utrecht, L P P Contribution Series No, 1.

[26]. Perveen, G. and Oaiser, S. (2007).The Amount of Pollen as a Regulator of Evolutionary plasticity of cross-pollinating plants "Doklady Biological Sciences" 234 N 1-6, 193-196. 
[27]. Randell B. R 1989. Revision of the Cassiinae in Australia. 2. Senna Miller sect. Psilorhegma (J. Vogel) Irwin and Barneby. Journal of the Adelaide Botanic Garden 12: 165-272.

[28]. Randell B. R 1990. Revision of the Cassiinae in Australia. 3. Senna Miller sect. Senna. Journal of the Adelaide Botanic Garden 12: $165-272$.

[29]. Randell B. R Barlow B. A 1998.Senna. Flora of Australia 12: 89-138.

[30]. Singh V 2001. Monograph on Indian subtribe Cassiinae (Caesalpiniaceae) Scientific Editions Jodhpur, India

[31]. Soladoye, M.O. ,Monsurat, a; Onakoyaec., and Mubo, as (2010). Morphometric Study of Genus Senna Mill. in South-eastern Nigeria. African Journal of Plant Science 4 (3) 044-052.

[32]. Tucker S. C 1996b. Trends in evolution of floral ontogeny in Cassia sensu stricto, Senna, and Chamaecrista. American Journal of Botany 83: 687-711.

[33]. Tona, M.I., and Elujoba, E.A., (2004). "In vitro anti-malaria activity of Cassia occidentalis, morindoides and phyllanthusniruri”.Ann. Trop. Med. Parasito195(1): 47-57.

[34]. Shaheen, S. M. Ahmad, S. Khalid, M. Zafar, A. Aftab and S. Sultana. (2013). Systematic and Phytochemical Evaluation of Selected Herbs of Family Fabaceae. Journal of Animal \& Plant Sciences, 23(3): 2013872 -881. 